\title{
KORONAVÍRUS ÉS A RUGALMAS ALKALMAZKODÁS, JÁRVÁNY ÉRTÉKEK MENTÉN
}

\author{
COVID -19 AND ATTITUDE OF RESILIENCE \\ PANDEMIC ALONG WITH SOCIAL VALUES
}

\author{
MiKLós ILONA PHD,adjunktus \\ EDUTUS Egyetem \\ miklos.ilona@edutus.hu
}

DOI $\underline{10.47273 / A P .2020 .20 .64-84}$

\begin{abstract}
ABSZTRAKT
Koronavírus járvány idején fenntarthatóság szempontjából fontos meghatározni, hogy milyen gondolkodásminták határozzák meg, hogy egyes társadalmak elönyösen vagy éppenséggel hátrányosan reagálnak vészhelyzet esetén. Az empirikus tanulmány olyan, az emberek gondolkodásmódjában tetten érhető jellemzőket keres, amelyek az aktuális járvánnyal kapcsolatos kihívások és a jellemző viselkedések előfordulására, értékrendjére világít rá. Az eredmények alapján megállapítható, hogy egyéni szinteken a reziliencia, a rugalmas alkalmazkodás képessége, fontos szerepet játszott a korlátozások idején, másrészt az erős családi kapcsolatok mellett a szolidaritás és a spiritualitás is fontos erőforrásokat jelentenek a reziliens viselkedés gyors adaptálásához.
\end{abstract}

Kulcsszavak: járvány, társadalmi értékek, rezilencia, fenntarthatóság

\begin{abstract}
In the time of the COVID-19 pandemic, it is important for sustainability to determine what patterns of thinking respond of certain societies in an emergency. The empirical study looks for characteristics of people's way of thinking, which examined the occurrence of the challenges related to the current epidemic and the occurrence and values of the characteristic ways of thinking. The empirical study looks for characteristics of people's way of thinking, which examined the occurrence and values of the challenges related to the current epidemic and the characteristic behaviors.

The results show that at the individual level, resilience, the ability to adapt flexibly, played an important role in times of constraints, on the other hand, in addition to strong family ties, solidarity and spirituality are important resources for rapid adaptation of resilient behavior.
\end{abstract}

Keywords: epidemic, social values, resilience, sustainability 


\section{Bevezetés}

Fenntarthatóság szempontjából a természeti vagy intézményi erőforrások mellett a gondolkodásminták is meghatározzák, hogy egyes társadalmak a hosszútávú fenntarthatóság szempontjából előnyösen vagy éppenséggel hátrányosan reagálnak bizonyos vészhelyzet esetén. A tanulmány arra keresi a választ, hogy milyen tényezök ösztönözték a társadalmi együttműködés fenntartását vagy megváltoztatását Magyarországon a 2020. március 11-én hivatalosan bevezetésre kerülő és június 18 -ig tartó kijárási korlátozás ideje alatt.

Megfigyelhető, hogy a járványkezeléssel kapcsolatos jelenlegi egészségügyi és gazdasági elemzések mellett egyre nagyobb szerephez jut az a kulturális magyarázat, amely lehetőséget adhat az egyéni viselkedések alapját meghatározható értékek bemutatására. Az egyes értékek és viselkedések, az uralkodó gondolkodásmód vagy közhangulat feltérképezése nagy jelentőséggel bírhat későbbi járványkezelések rövid és hosszútávú vizsgálataiban.

A koronavírus megfékezése érdekében elrendelt védőeszközök kötelező használata és a terjedés lelassítása érdekében hozott lezárásokkal és bezárásokkal járó intézkedések vegyes fogadtatásra találtak a társadalom különböző részein, hiszen sokan összeegyeztethetetlennek tartották a közjavakat képviselő közegészség érdekében hozott szabályokat saját, személyes értékeikkel. Ez a konfliktus az egyik legjelentősebb társadalmi kihívás, amely elsőként kimutathatóvá vált a vírus idején, hiszen ez azt jelenti, hogy az embereknek választaniuk kell a saját előnyük maximalizálása és a társadalmi jólét előmozdítása között, viszont a nagyobb társadalmi csoportokat érintő vészhelyzetek, mint amilyen koronavírus járvány is, összeférhetetlenséget jelentenek az egyéni és társadalmi jólét között.

Éppen ezért érdemes megvizsgálni, hogy közel fél évvel az első intézkedések bevezetése óta, a megelőzés mennyire sikeresen támaszkodhat a társadalomra, hiszen amilyen hajlandóság mentén használja a lakosság az elöírt védőeszközöket, az azt mutatja meg, hogy milyen mértékben hisznek a járvány megelőzésében játszott saját szerepükben és a kormányzati intézkedésekben.

A tanulmány arra keresi a választ, hogy a globális járvánnyal kapcsolatos megelőző intézkedések a társadalmi közjó érdekében 1.) kapcsolhatók-e egyéni szinten a reziliencia, a rugalmas alkalmazkodás, társadalmi szintü adaptálási képességéhez, 2.) képesek-e az emberek alkalmazkodni a kialakult helyzethez, 3.) a reziliencia milyen erőforrások mentén tud kibontakozni. 
Az empirikus kutatás, hólabda módszerrel, 2020. március 23. és április 4. között egy 26 kérdésből álló, Qulaitrics online kérdőív segítségével gyüjtött adatbázisra épül. A kutatás limitációja, hogy módszertanát tekintve nem reprezentatív, hiszen az internetelérés és digitális eszközhasználat nem egyenlően biztosítottak Magyarországon. Annak ellenére, hogy az EU átlaghoz közeli volt a KSH 2018-ban kiadott elemzése alapján (KSH; 2018) az internettel rendelkező háztartások aránya, és azzal, hogy magyarországi háztartások 83\%-a rendelkezett szélessávú internetkapcsolattal, ez az arány csupán az uniós rangsor középső harmadára volt elegendő.

A cikk eredménye azt mutatja, hogy hazánkban a reziliencia és a fenntartható fejlődés szempontjából meglehetősen vegyes értékekkel ötvözött, és sokszor önellentmondásos viselkedések mutathatóak ki. A kognitív disszonancia kimutatására, a limitált mintanagyság ellenére, a kapott eredmények alapján az elemzés alkalmas az adott időszakot meghatározó és bemutató értékek feltérképezésére.

\section{Elméleti keret}

A koronavírusról (COVID-19) először 2019. december 31-én számoltak be Wuhanban, Hubei tartományban, Kínában három hónappal később pedig már világjárvány kitöréséről tudósítottak a nemzetközi hírek. A vírus első, hivatalos megjelenése óta egyre több elemzés születik a sokk kezeléséről és annak várható hosszáról és hatásairól. A legtöbb korai elemzés a gazdasági életben megtapasztalt széles körü zavarokat mutatja be: a globális ellátási láncok megroppanását, a szolgáltatások iránti kereslet leszükülését, a turizmus visszaesését, viszont szembetünő, hogy a gazdasági mutatók mellett a koronavírus az emberek napi rutinját, életmódját sem kímélte.

Ahhoz, hogy a koronavírussal, a járvánnyal kapcsolatos attitűd mértéke és a rugalmas alkalmazkodás képességének formái mérhetővé válhassanak, elsőként a korábbi nemzetközi és hazai kutatások vizsgálatai kerülnek bemutatásra, ugyanis a járványkezeléssel, félelemmel és a jövővel foglalkozó értékvizsgálatok arra világítanak rá, hogy a társadalmi és az egyéni megküzdés képességei nem minden esetben egyértelműek, és az eltérések sok esetben nem a gazdasági, hanem a kulturális értékbeli különbségek miatt alakulnak ki. 


\subsection{Normák, értékek, attitüd}

Az emberi közösségek müködőképességének feltétele, hogy a közösség tagjai bizonyos viselkedési szabályokat, normákat kövessenek, ellenkező esetben, ha a közösség tagjainak magatartása kiszámíthatatlan, akkor az együttmüködés lehetetlenné válik.

A normákhoz szorosan kapcsolódnak az értékek, amelyek megadják a norma tartalmát. Az értékek olyan kulturális alapelvek, amelyek kifejezik, hogy az adott társadalomban mit tartanak fontosnak, kívánatosnak, jónak és rossznak. Az értékek koronként változhatnak, sőt társadalmi osztályonként is különbségek lehetnek, viszont érdemes szem előtt tartani, hogy minden közösségnek, a társadalomnak legyenek olyan értékei, amelyek kizárólag az adott társadalom tagjai számára jelentenek viszonyítási alapot.

Az értékek elsajátítása (internalizálása) azt a folyamatot jelenti, hogy az egyén az értékekkel milyen mértékben azonosul. Tehát nem a szankciótól való félelem miatt normakövetö, hanem azért, mert számára a követendő magatartás a helyes magatartást jelenti (Spéder; 2006).

Normakövető viselkedés létrejöhet azért, mert az egyén fél a következményektől, vagy a normasértés miatti hátrányoktól, ezért mindenki számára előnyösebb, ha a társadalom tagjai saját meggyőződésből követik a normát, azonosulnak azzal, érvényesül a viselkedésükben, mert értékként ismerik el a normában foglaltakat.

Az érték kategóriához kapcsolódó fogalom az attitűd. Az attitűd az egyénnek az a szellemi és lelki képessége, hogy bizonyos tárgyakra, helyzetekre, személyekre meghatározott módon reagáljon. Az attitüdök hátterében általában értékek állnak. Az attitüd és az érték közötti különbség abban áll, hogy az attitüd, mint viszonyulás mindig konkrét kérdésre, helyzetre, míg az érték általános helyzetre vonatkozik (Spéder; 2006 in Andorka 2006).

A koronavírussal kapcsolatos kommunikációkban az egyes országokban számos esetben kerültek napvilágra ellentmondásos vélemények és intézkedések a szájmaszk használatának jogossága, a társadalmi távolságtartás, boltbezárások, kulturális események korlátozása terén. Nemcsak a nemzetközi szervezet, a WHO hozzáállása volt ellentmondásos, de a nemzeti kormányok intézkedései között is sok ellentétes nézőpont alapján hoztak politikai döntést.

Míg a svédek és az angolok szabadjára engedték a koronavírust a nyájimmunitás elérése érdekében, addig az Európai Unió többi országa bezárt. A svéd modell végül egyedül maradt az Unióban, mert az Egyesült Királyság elég hamar elmozdult a lezárás felé, ahol az emberek kapcsolatainak korlátozását, a járvány terjedésének "késleltetését" igyekeztek elérni, mivel a 
védekezési taktika fő elemét csupán kormányzati intézkedésekkel nem tudták kontrollálni. Ezzel szemben a svédek következetesen tartják magukat ahhoz az elgondoláshoz, hogy a koronavírussal való fertőzés az esetek többségében, és a nem különösen veszélyeztetett csoportok tagjaiban enyhe lefolyású, sőt akár majdnem tünetmentes is lehet. „Nem hozhatunk olyan drákói döntéseket, amelyek mérsékelt hatással lennének a járványra, de cserébe leállitanák a társadalom müködését." mondta Johan Carlson.

Más kérdés, hogy ebben az időszakban ez egyes társadalmak miképp gondolkodtak a leállásról és a COVID-19 világjárványról, és a tapasztalatokat milyen hiedelmekkel kapcsolják össze egyéni szinten. Az első hetekben, Európából és Észak-Amerikából érkező tömeges élelmiszerfelvásárlásokról szóló hírek azon a félelmen alapultak, hogy mások már mekkora tartalékokat halmoztak fel (Corkery és Maheshwari, 2020). Amikor széleskörben elterjedt, hogy a boltokban alapélelmiszereket és WC-papírt halmoznak fel egy távolabbi, nem ismert jövő érdekében, akkor azoknak a viselkedése, akik megtagadták a felhalmozást, azok sok esetben a közjó érdekeit szolgálta.

\subsection{Társadalmi magatartás}

Az egyes országok társadalmi hálózatokból és egymásba fonódó társadalmi hálózatokból állnak. Mind a társadalmi kontroll, mind a szociális támogatás függ a szoros és laza kapcsolatok komplex struktúrájától. A relatív társadalmi stabilitás időszakaiban a társadalmi magatartást gyakran olyan tényezők határozzák meg, mint személyes értékek, anyagi korlátok, törvények, társadalmi normák stb. Ez azt jelenti, hogy ezen tényezők egyikében bekövetkezett változást gyakran a stabilitás felszívja, míg a többi tényező ellensúlyozza (Tankard és Paluck, 2017; Vallacher, Read, Nowak, 2002).

A társadalmi magatartás stabilitásának és kiszámíthatóságának ebből következő intuitív megértése azonban nem elegendő ahhoz, hogy megértsük, hogy mi történik a válság idején. Amikor a lakosság mindennapi élete jelentős fordulatnak van kitéve, a sokk egyszerre érintheti a társadalmi viselkedés több, vagy akár az összes meghatározóját. Több tényező közötti kölcsönhatás egyidejüleg felgyorsítja a stabilitás felbomlását (Elcheroth és Reicher, 2017; Vallacher et al., 2002). A felbomlással létrejövő magatartás rendkívüli rugalmasságot, gyors alkalmazkodást követel meg, miközben a lakosság a hatóságokat a válság idején esetleges rendellenességük okozójának és forrásának tekinti. Úgy tűnik azonban, hogy ez az egyénektől eredő, különböző szintủ és erősségű alkalmazkodóképesség nagyban megkönnyíti a viselkedés 
új követelményekhez történő alkalmazkodását, olyan mértékben és olyan sebességgel, amely normális körülmények között elképzelhetetlen lenne.

Az egyes egyének azon képessége, hogy képessé váljanak egy-egy környezetüket érintő gazdasági, természeti vagy társadalmi katasztrófával való megbirkózásra, az az általuk kiépített szociális hálózatok méretétől és erősségétől függ. A kutatók azt is megállapították, hogy a társadalmi és gazdasági integráció mértéke egyszerre befolyásolja a szociális hálózatok közötti laza kapcsolatok erősségét. A szociális hálózatok sürü szerkezete által biztosított ellenállóképesség révén válnak képessé arra az emberek, hogy reagálni tudjanak az őket ért mind a jó, mind a rossz hatásokra.

\subsection{Félelem és megküzdés}

A járvány idején az egyik központi érzelmi válasz a félelem. Az emberek, mint más állatok, védelmi rendszerekkel is rendelkeznek az ökológiai veszélyek leküzdésére. A fenyegetésből származó negatív érzelmek fertőzőek és rombolóak is lehetnek. Cole et al. (2017) szerint a félelem bizonyos helyzetekben hasznos lehet, másokban nem: a félelemre való hivatkozás egyrészt arra készteti az embereket, hogy megváltoztassák viselkedésüket, ha úgy érzik, hogy képesek kezelni a fenyegetést, másrészt védekező reakciókat is kiválthatnak, amikor tehetetleneknek tünik a helyzettel való megbirkózást.

A Miskolci Egyetem ATTI kutatócsoportjának járványösszefoglaló tanulmányának célja a járványhelyzet akut időszakának szociológiai feltérképezése volt. Az elemzés kiindulásaként azt feltételezték, hogy a kijárási szigorítások időszaka többféleképpen értelmezhető és többfélképpen átélhető. Abból indultak ki, hogy a megküzdés fogalmának értelmezésére már korábban számos pszichológiai modell született.

Lazarus és Folkman (1988) a félelemmel kapcsolatban két átfogó megküzdési stratégiát ír le. A problémaközpontú megküzdés során az egyén célja a probléma leküzdése, kezelése, vagy jövőbeli elkerülése. Az érzelemközpontú stratégiák esetében viszont a cél az érzelmi stresszreakciók enyhítése, a negatív érzelmek túláradásának csökkentése. Ezt a két stratégiát egy-egy helyzetben lehet vegyesen használni és általában ideiglenesen, addig, ameddig a végleges megoldási módra rá nem lelünk.

A Miskolci Egyetem fenti 2020-as, empirikus kutatásában szembeötlő eredményként azt tartották a kutatók, hogy a járványügyi helyzetet sokan nagyon félelmetesnek és nagyon riasztónak jellemezték. Mindezt elsősorban a kiszolgáltatottság és bizonytalanság miatt, hiszen 
a felmérés idején még - a járvány akut - szakaszában nem lehetett elöre tudni, hogy hogyan fog alakulni a fertőzés mértéke Magyarországon. Sokan tartottak attól, hogy idős hozzátartozóik megbetegszenek. Sokan féltek a járvány gazdasági hatásaitól. Többen kifejezték az iránti aggodalmukat, hogy nem látható a járványhelyzet vége és az egész helyzet nagyon kiszámíthatatlan.

Korábbi járványkutatások szerint az országos védőintézkedések sikere sokszor attól függ, hogy az egyes társadalmi csoportok és egyének mennyire tartják hatékonynak az elrendelt intézkedéseket, mennyire tudnak azonosulnak velük vagy mennyire utasítják el azokat (Peters, Ruiter, és Kok, 2013; Sheeran, Harris, Epton, 2014). Az említett kutatók vizsgálatai azt is megállapították, hogy a félelem átkeretezése az egészségügyi kockázatok szélesebb körben való megismerésével kapcsolatban jelenthet sikeres megelőzést. Minél intenzívebbek és szélesebb körben zajlik a dohányzás veszélyeiről és a rák kockázatairól való társadalmi kommunikáció, annál nagyobbak a félelemből eredő társadalmi reakciók, vagyis a szürésre és a megelőzésre való hajlandóság.

Rimal és Juon (2010) kutatásai szerint a félelem ébrentartása kizárólag akkor müködik, ha mind az üzenet hatékonysága és a fenyegetés szintje elég magas. A félelemmel való megküzdés hatásossága és a fenyegetés alapszintje viszont egyénenként változó, ezért viselkedésnél többféle reakciók születhetnek: egyesek közömbösek lehetnek (alacsony fenyegetés, alacsony hatékonyság mellet), mások elkerülö (avoidant) magatartást választanak (nagy fenyegetés, alacsony hatékonyság mellett), míg vannak, akik proaktívakká válnak (alacsony fenyegetés, nagy hatékonyság alatt), de akadnak, akik érzékenyen reagálnak (nagy fenyegetés, nagy hatékonyság mellett).

A félelemre, mint érzelemre adott válaszok a közül a pszichológia James-Lange (in: ThorneHenley; 2000) által képviselt elmélete alapján azt mondja, hogy a környezet a testi válaszokon keresztül, közvetett módon váltja ki, ellentétben azzal a korabeli elképzeléssel, hogy az érzelmi élményt közvetlenül az észlelt tárgy vagy esemény váltja ki. James-Lange elmélete alapján tehát először sírunk és aztán leszünk szomorúak, először elfutunk, és utána félünk, vagy először ütünk, és utána leszünk dühösek. Az érzelmek tehát az ingerre adott reakcióink biológiai kimenetele, az érzelemkeltő helyzetek bizonyos testi válaszokat váltanak ki, és ezeknek a válaszoknak a bennünk kialakuló tudatossága az érzelem érzése. 
A pszichológia kognitív modellje (Beck, 2001) alapján az egyén gondolkodásmódja, döntései és végeredményben a viselkedése úgynevezett sémák mentén szerveződik. A sémák általában gyermekkor-ban jönnek létre, sokszor valamilyen kellemetlen, de leginkább valamilyen traumatikus élmény (szeretett személy halála, megszégyenítés, abúzus stb.) hatására. Az egyént egész élete során nagymértékben befolyásolja az az elakadás, amelyet az adott élmény okozott. Mindezekből az következik, hogy az egyén traumatikus élményeivel való megküzdésének képessége és annak társadalmi támogatottsága nagyban meghatározza a társadalmi értékrend fejlödését és ezen keresztül a környezetterhelését is.

\subsection{Jövö és döntéshozatal}

Felmerül tehát az a kérdés, hogy vajon milyen értékek vezetik az egyéneket a félelem észlelése során? Elfogadják-e a koronavírus idején hozott rendelkezéseket, mint például a maszkhasználatot, a társadalmi távolságtartást vagy éppen az élelmiszer felhalmozásra fókuszálnak?

A döntéshozatallal foglalkozó elméleti és empirikus kutatások már korábban is vizsgálták, hogy miben különböznek az egyének egymástól az egyes védőintézkedések alkalmazása során. Vajon az egyéni viselkedés összekapcsolható-e az egyének társadalmi értékorientációjával (Messick és McClintock, 1968). vagy a társadalmi kockázatvállalás inkább személyiségjegyekhez köthető (Leder és Betsch, 2016)? Ezek a felmérések arra voltak kíváncsiak, hogy vészhelyzetben az egyének inkább önmagukat védik-e, vagy másokat is szem előtt tartva hoznak döntést az intézkedésekkel kapcsolatban.

Magyarországon a Friedrich Ebert Alapítvány kutatása a vírus utáni, lehetséges jövőképekről való diskurzusok gyüjteménye is lehetne. Tanulmányukban a szerzők kísérletet tettek arra, hogy összegyüjtsék azokat a jó európai gyakorlatokat helyi szinteken, amelyek progresszíven hatással lehetnek a későbbi, vírus utáni időszakra. A kutatócsoport megállapítása szerint a pandémia nemcsak a fizikai, hanem a mentális egészségre nézve is súlyos fenyegetést jelent mind a halálfélelem, mind a magány, mind a járulékos életszínvonal-romlás következtében. A jövőtől való szorongás és félelem, mint érzelmi állapot sokféleképen magyarázható, látható, hogy tudományosan is számos elmélet hangsúlyozza az érzelmek komplexitását-

\subsection{Reziliencia}

A reziliencia fogalmát a kutatók meglehetősen eltérő problémákra és módokon alkalmazzák. A Nemzetközi Reziliencia Projekt definíciójában: „A reziliencia olyan univerzális képesség, 
amely lehetővé teszi egy személy, egy csoport vagy egy közösség számára, hogy megelözze, minimálisra csökkentse vagy legyözze a megpróbáltatások káros hatásait." (Grotberg 1996).

A reziliencia fogalma párhuzamosan, de függetlenül terjedt el a pszichológiában (Robinson, Carson; 2016), ahol nagyjából hasonló tartalommal, de individumokra és csoportokra is alkalmazzák (Bonanno; 2004).

A társadalomtudományokban a reziliencia-alapú kutatásokban az ember nemcsak a külső hatások kiváltója, hanem azok elszenvedője is (Berkes, Folke;1998; Folke; 2006). A legtöbb, rezilienciával kapcsolatos kutatás a társadalmi csoportok külső hatásoknak való kitettségével, sérülékenységével, ellenálló vagy helyreálló képességével foglalkozik (Campanella 2006; Keogh et al. 2011), továbbá olyan meghatározó nagy természeti katasztrófák, mint amilyen a Katrina hurrikán (2005) hozzájárultak a reziliens gondolkodás elterjedéséhez (Lang 2011).

A természeti katasztrófák mellett egyre gyakoribbakká váltak ember által okozott katasztrófák, ahogy a 2001. szeptember 11-i terrorfenyegetettség és a biztonság kérdéskörével (Coaffee 2008) a reziliencia megfogalmazása újabb szakaszhoz érkezett.

Bourbeau (2013) megkülönbözteti a reziliencia ökológiai és szocioökológiai típusát, aki szerint a legösszetettebb rendszer az emberi társadalmak és a környezet közös szocioökológiai metarendszere, amelyhez képes a csak ökológiai vagy csak társadalmi rendszerek vizsgálata szükségképpen leszükített). Székely szerint a reziliencia nem kétállapotú fogalom, ami vagy van, vagy hiányzik, hanem számtalan foka, megnyilvánulási formája létezik, melyek időhöz való viszonya is eltérő lehet (Székely, 2015).

Az emberek a számukra hátrányos változásokat - például szabadságjogaik csorbítását -, amennyiben azok igen lassan következnek be, hajlamosak egészen addig figyelmen kívül hagyni, amíg a hatás felismerése már túl későn történik meg ahhoz, hogy hatásos reziliens reakciót indukálhasson.

Tudományos, hazai vizsgálatokban mindezidáig azonban még nem vizsgálták, mennyire alapozták meg a védőintézkedések sikeres alkalmazását a szubjektív értékek, mennyire tudnak az egyének azonosulni a központilag meghozott intézkedésekkel, sok esetben korlátozásokkal.

A cikk a következőkben egy online empirikus kutatási eredményeire alapozva arra keresi a választ, hogy Magyarországon a kijárási korlátozások illeszkedtek-e az egyéni döntések mögött 
húzódó értékekhez illetve, hogy a korlátozások milyen lemondásokkal és értékprefenciákkal párosultak az egyéni és a közjó érdekében.

\section{Módszertan}

A kvantitatív kutatás strukturált módszere, amelyet jellemzően a vizsgált sokaság statisztikai jellemzésére és az azonosított összefüggések számszerüsítésére alkalmaznak (Neulinger 2016). A 21. század egyik nagy vívmánya, hogy az online felületek kiváló platform lehetőséget biztosítanak empirikus kutatások számára. Az online felületeket és csatornákat viszonylagos rugalmasság jellemzi, hiszen egyaránt lehetőséget biztosít nyílt vagy zárt csoport számára, akár a Facebook felületén vagy azon belül zárt csoportokban vagy e-mailbe beágyazott felméréssel dolgozik a kutató. (Fricker és Schonlau, 2002; Malhotra et al. 2004;). Érdemes megemlíteni, különösen a bezárulással együttjáró járványkezelés idején a különböző média és közösségi média által kínált platformok révén erős érzelmi kötődések és bizalmi viszonyok alakíthatók ki fizikai távolságtól mentesen, így az online térben vizsgált nyilvánosság nem minden esetben tekinthető reprezentatív véleménynek. A primer kutatás a Qualitrics online rendszer segítségével összeállított kérdőív eredményei alapján, a 2020. március 23. és április 04. között $\mathrm{N}=64$ fős válaszadó adatait dolgozta fel, többváltozós statisztikai elemzéssel. Az empirikus kutatás arra keresett választ, hogy miképpen jellemezhető a magyar járvány profil, milyen manifeszt értékek befolyásolják a járvánnyal kapcsolatos viselkedéseket Magyarországon. Két változóhalmazt különböztetünk meg alapvetően egymástól, míg az egyik a közvetlenül megfigyelhető, mérhető, ez a manifeszt változók halmaza, addig a másik a közvetlenül nem mérhető, látens változók, faktorok halmazát jelenti. A mérés minőségének két legfontosabb eleme a mérés érvényessége (validity) és a mérés megbízhatósága (reliability). A két komponens nem független egymástól mivel, ha a mérés nem megbízható, nem lehet érvényes sem (Füstös; 2018). A kutatás a manifeszt viselkedések és értékek feltérképezésére többfokozatú attitüd skálával mért descriptives mean értékek alapján felállított sorrendiséget hasonlított össze.

\section{Elemzés}

\subsection{Demográfia}

A felmérés reprezentativitását nem csak a mintavétel módja, hanem nagysága $(\mathrm{N}=60)$ is korlátozza, emellett a nemek és az életkor aránya is torzítást mutatnak az átlag magyar 
populációt tekintve. A nők 65\%-os válaszadási hajlandósága mellett (39fö), a férfiak 35\%-ban (21 fó) képviselték magukat az online felmérésben.

Az életkori változók alapján ( $\mathrm{N}=60)$ mellett a 16-21 évesek 8,64\%-ban, a 22-35 éves korcsoportból 32, 68\% , a 36-50 évesek aránya 43,50\% , 51-64 évesek 13,39 \%, 65-80\% 1,79 $\%$; az online felmérésben 80 éve feletti személy nem képviseltette magát.

A válaszadók $61,1 \%$ aktív munkavállalónak tartja magát, míg 7,21 \% részmunkaidőben dolgozott a válaszadás ideje alatt. 11,98\% fóállású vállalkozóként, míg diákként 14,01\% regisztrálta magát. A munkanélküli, de munkát kereső aránya 1,48\%, míg a nyugdíjasok aránya a válaszadók között 3,07\% volt.

A válaszadók családi állapotát tekintve 34,95\% házasságban, míg 34,17\% kapcsolatban élőként jellemezte magát. Az elváltak 3,26, viszont özvegyek csupán 1,46\%-ban képviseltették magukat, az egyedülállók, soha házasságban nem élők aránya 26,13 \%-os volt a felmérés idején.

A kétnyelvü, angol-magyar kutatás válaszadói 91,67 \%-ban Magyarországon élnek, míg a külföldi válaszadók aránya 8,33\%. A külföldi válaszadók Németországot, Szerbiát, Kínát, Olaszországot, Svédországot adták meg a felmérés ideje alatt állandó tartózkodási helyüknek.

A fóvárosban a válaszadók 29,30\%-a élt, míg a fóvárosi agglomerációt 19,02\% adta meg életvitelszerü lakóhelyként. Kisvárost a válaszadók 18,8 \% -a adta meg lakóhelyéül, míg falun $15,66 \%$ él.

\subsection{A kijárási korlátozás}

A kijárási korlátozással bevezetett intézkedések során megváltozott a társadalom minden tagjának a fontossági sorrendje.

Az aktuális és a jövőbeli viselkedés jellemzőinek feltérképezésére (2. táblázat) 7 állítás került 6 fokozatú skálán vizsgálatra, descriptives mean értékek összehasonlításával. Az 1-6 -ig terjedő skálán a fontos értékek az 1-essel jelölt prioritások voltak, míg a magasabb átlagok a kevésbé fontos szempontokat értelmezik. A vizsgálat során önálló választással azok az értékek kerültek összehasonlításra, amelyek a kijárási korlátozásokra vonatkozott a MOST és a JÖVŐ idősíkban jelenthetnek fontossági sorrendet.

A munkahelymegtartás $(2,13)$, a háztartási bevételek biztosítása $(2,42)$ és utóbbi kontrollálása vált $(3,01)$ a legfontosabb prioritásává a magyar családoknak. A kijárási időtartam 
bizonytalansága, a rendszerszintü leállások sokakat elbizonytalanítottak és inkább kockázatkerülővé váltak, semmint a jövővel kapcsolatos hosszútávú tervekben való gondolkodást engedhették meg maguknak.

1. táblázat: A kijárási korlátozással egyidőben milyen fontossági szempontok változtak meg az életében?

\begin{tabular}{|l|l|l|}
\hline \multicolumn{4}{|l|}{$\begin{array}{l}\text { A következő kérdésnél arra vagyunk } \\
\text { kíváncsiak, hogy az Ön fontossági } \\
\text { sorrendje hogyan változott meg a } \\
\text { kijárási korlátozás óta? }\end{array}$} \\
\hline & $\begin{array}{l}\text { Munkahely megtartás/ munkahelyi } \\
\text { követelményeknek való megfelelés (1) }\end{array}$ & 2,13 \\
\hline $\mathbf{1 .}$ & Háztartási bevételek biztosítása (2) & 2,42 \\
\hline $\mathbf{2 .}$ & Háztartási kiadások kontrolálása (3) & 3,01 \\
\hline $\mathbf{3 .}$ & Lakhatás biztosítása (4) & 3,55 \\
\hline $\mathbf{4 .}$ & Utazás/logisztika (5) & 5,36 \\
\hline $\mathbf{5 .}$ & Befektetési lehetőségek keresése (6) & 5,69 \\
\hline 6. & $\begin{array}{l}\text { Nyugdíjjárulék/jövőről való } \\
\text { gondoskodás (7) }\end{array}$ & 5,84 \\
\hline 7. & & \\
\hline
\end{tabular}

Forrás: saját elemzés

A következőkben annak a fontossági sorrendjére (3. táblázat) kérdezett rá a kérdőív, hogy melyek azok a mindennapi tevékenységek, amelyek jelentősége megnövekedett a kijárási korlátozásokkal; az 1-10-ig terjedő Likert skáláknál a legfontosabb értéket a 10-es jelezte, míg a legkevésbé jelentőset az 1-es jelentette.

Látható, hogy a maximálisan elérhető 10 -es skálán az egészségmegőrzés vezeti a listát $(8,62)$. A járványtól való félelem, a közegészségügyi szempontok betartásának fontossága után a második legfontosabb értéket az internetelérés kapta (7,89). A 21. század digitalizációja a home office-szal és az online oktatás bevezetésével érkezett meg Magyarországra, így a legtöbb aktív háztartás számára extra terheket rótt a digitális eszközökkel való ellátottság, de egyes településeken a digitális hozzáférés folytonosságának biztosítása is.

Meglepő módon a digitális világba való beilleszkedés után, harmadik helyen $(7,55)$, megelőzve a megfelelő mennyiségű otthoni élelmiszer biztosítását $(7,08)$, a meglévő házastársi kapcsolatok működtetése jelentette. A fizikailag összezárt családok számára extra feszültséget jelentett az egymással való együttélés, és a bizonytalanság mellett a terek újrafelosztása, illetve a feladatok újraütemezése extra erőforrásokat igényeltek. A középmezőnybe szorult rendszeres takarítás $(6,51)$, az Énidővel való lavírozás $(6,44)$ és a betegek ápolása $(6,13)$ úgy tűnik, korábban is megfelelő rugalmasságot vártak el az egyéntől bár meglepő módon a karantén 
idején a gyerekekkel való foglalkozás $(5,52)$ alig előzte meg a háziállatok napi ellátását $(4,99)$. A lista alacsony prioritásai közé szorult a jövőre való fókuszálás.

A mindennapi MOST helyzetek megoldásaiban az élet értelmének megtalálását $(4,34)$, vagy akár a rájuk szakadt szabadidőben egy új hobby $(3,07)$, az öltözködés $(3,03)$ vagy társ $(1,47)$ keresésének fontosságát is elhalasztották.

2. táblázat A kijárási korlátozással milyen területeken változott meg a fontossági sorrend

\begin{tabular}{|c|c|c|}
\hline & $\begin{array}{c}\text { A következő kérdésnél arra vagyunk kíváncsiak, hogy az Ön } \\
\text { fontossági sorrendje hogyan változott meg a kijárási korlátozás } \\
\text { bevezetése óta? }\end{array}$ & Mean \\
\hline 1. & Egészségmegőrzés és egészségtudatosság (8) & 8,62 \\
\hline 2. & Internetelérés biztosítása (4) & 7,89 \\
\hline 3. & Meglévő házastársi, élettársi kapcsolat müködtetése (5) & 7,55 \\
\hline 4. & Megfelelő mennyiségü élelmiszer otthoni biztosítása (6) & 7,08 \\
\hline 5. & Takarítás (14) & 6,51 \\
\hline 6. & Saját idő és hely megtartása (7) & 6,44 \\
\hline 7. & Idősek/ betegek gondozása (2) & 6,13 \\
\hline 8. & Gyerekekről való gondoskodás (1) & 5,52 \\
\hline 9. & Házi kedvencek tartása (3) & 4,99 \\
\hline 10. & Szabadidő, kirándulás, sport, kultúrára fordított idő biztosítása (9) & 4,80 \\
\hline 11. & Élet értelmének megtalálása (13) & 4,34 \\
\hline 12. & Új hobby megtalálása (11) & 3,07 \\
\hline 13. & Öltözködés (10) & 3,03 \\
\hline 14. & Társkeresés (12) & 1,47 \\
\hline
\end{tabular}

\subsection{Akadályok és ütközési pontok}

A kijárási korlátozással kapcsolatos értékek feltérképezés után, 15 olyan állítást vizsgáltunk (4.táblázat) 10 fokozatú skálán, descriptives mean értékek összehasonlításával, amelyek a korábbi napi rutin elmaradásával kapcsolhatók össze. A megadott állítások közül 1-10-ig terjedő Likert skálán azt kellett a válaszadóknak meghatározni, hogy az életük mely területén érezték magukat elhanyagoltnak, illetve mely tevékenységek megszünése miatt érezhették magukat elhagyottnak. A lista egyben a személyes élmények, kötődések és kapcsolódások korlátázását, a tehetetlenség érzetét és frusztrációját ábrázolja a kapott értékek alapján. 
3. táblázat Napi tevékenységek akadályoztatása a kijárási korlátozás alatt

\begin{tabular}{|c|l|l|}
\hline & $\begin{array}{l}\text { A következökben arra vagyunk kíváncsiak, } \\
\text { hogy Ön mennyiben érzi magát } \\
\text { akadályoztatva az alábbi tevékenységekben? }\end{array}$ \\
\hline $\mathbf{1 .}$ & $\begin{array}{l}\text { Barátok/társaság személyes kapcsolatok ápolása } \\
\text { (5) }\end{array}$ & 6,35 \\
\hline $\mathbf{2 .}$ & Utazás (3) & 6,14 \\
\hline $\mathbf{3 .}$ & $\begin{array}{l}\text { A külső eseményekbe való beavatkozás } \\
\text { lehetősége (13) }\end{array}$ & 5,79 \\
\hline $\mathbf{4 .}$ & Anyagiak biztosítása (4) & 5,71 \\
\hline $\mathbf{5 .}$ & Bevásárlóközpontokban, üzletekben vásárlás(8) & 5,50 \\
\hline $\mathbf{6 .}$ & Szabadság, önrendelkezés (1) & 5,03 \\
\hline $\mathbf{7 .}$ & Munkavégzés (9) & 4,32 \\
\hline $\mathbf{8 .}$ & Családi élet (10) & 4,11 \\
\hline $\mathbf{9 .}$ & Személyes biztonság (2) & 4,02 \\
\hline $\mathbf{1 0 .}$ & Tanulás (12) & 3,67 \\
\hline $\mathbf{1 1 .}$ & Templomba járás (11) & 3,66 \\
\hline $\mathbf{1 2 .}$ & Változatos étkezés (15) & 3,58 \\
\hline $\mathbf{1 3 .}$ & Szex (6) & 3,39 \\
\hline $\mathbf{1 4 .}$ & Drog (7) & 2,27 \\
\hline $\mathbf{1 5 .}$ & Alkohol (14) & 2,05 \\
\hline & &
\end{tabular}

Forrás: saját elemzés

A válaszadókat a szociális háló befagyása érintette leginkább $(6,35)$ személyesen. Elmondásuk szerint a baráti kapcsolatok ápolásáról és az utazásról $(6,14)$ való kényszerü lemondást volt frusztrációjuk alapja a kijárási korlátozások bevezetésével. A külső körülményekbe való bele nem avatkozás lehetősége $(5,79)$ szintén okozója lehet annak, hogy a fizikai korlátozások ideje alatt a többség „,béna kacsaként” jellemezte helyzetét.

Érdekes módon a személyes kapcsolatok hiánya és korlátozása nem jelentette, hogy a változatos étkezéshez, a szexhez, a droghoz és az alkoholhoz való hozzájutás vagy éppen ezekről való lemondás a válaszadók számára problémát okozott volna, vagy éppenséggel egyáltalán nem érezték ezekben akadályozva magukat. Ezek az alacsony értékek nemcsak azt jelenthetik, hogy korlátlanul állt rendelkezésükre, hanem azt is, hogy ezek a viselkedések és tudatmódosító szerek nem képezték a COVID előtti mindennapi életük részét.

\subsection{Erőforrások}

Az online kérdőív nyitott kérdésként kérdezett rá arra, hogy az egyes válaszadók milyen erőforrások mentén töltekeznek a kijárási korlátozások idején. A válaszadók által megosztott gondolatok alapján személyes kapcsolatok és spirituális kötődések között változatos és színes alkategóriák születtek (1. ábra). 
1. ábra Személyes és sprituális kötődések, mint erőforrások COVID-19 idején bevezetett kijárási korlátozás idején

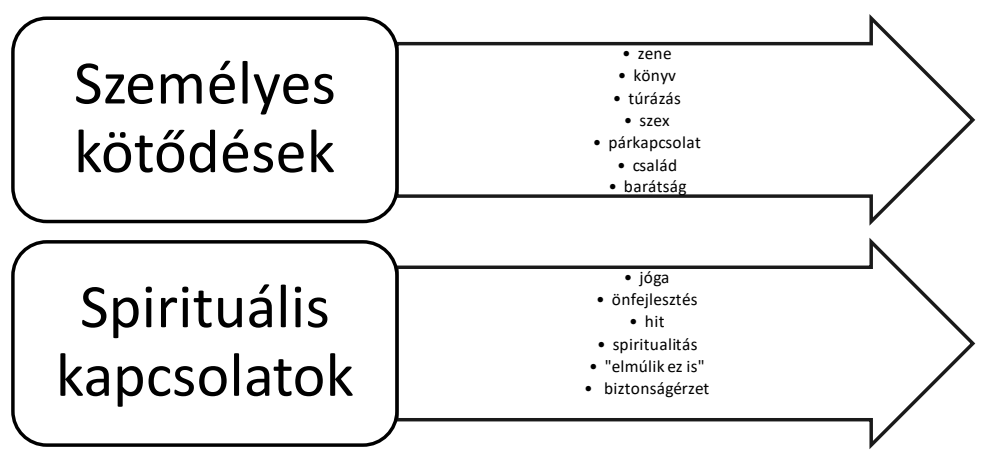

Forrás: saját elemzés

\subsection{Problémakezelés és megoldási módok}

A felmérés során a válaszadók felismerték annak jelentőségét, hogy összefogásra és közös cselekvésre van szükség. A koronavírus nem csupán beazonosítható, távoli közösségeket érintő probléma, hanem globális kihívás, amely hatással lesz a következő évekre.

A válaszadók az értékelés szerint (5.táblázat) viszont legkevésbé sem látnak a válságban lehetőségeket. Az eredmények alapján elég szembetűnő, hogy a tudományos eredményekben kevésbé bíznak $(6,04)$ a válaszadók, mint a politikusi és állami szintű döntéshozatalban $(7,14)$. Holott arra a korábbi kérdésre, hogy hisz-e a politikusokban, 21,45\% állította, hogy hisz. Az eredmények alapján látható, hogy az ellentmondások ellenére az összeesküvéselmélet hívei nem kaptak teret $(4,72)$, de az egyénieskedők sem. Járványhelyzet idején az egyénieskedés, a saját utas megoldások nem elfogadhatóak a többség szerint.

4. táblázat Megküzdési módok és lehetőségek

\begin{tabular}{|c|l|c|}
\hline & $\begin{array}{l}\text { A következőkben arra vagyunk kíváncsiak, hogy Ön szerint a } \\
\text { magyar társadalomban 10 ember közuil mennyien tartják } \\
\text { jellemzőnek az alábbi felsorolásokat? }\end{array}$ & Mean \\
\hline $\mathbf{1 .}$ & Egy társadalomban és a világnak most össze kell fogni. (10) & 7,78 \\
\hline $\mathbf{2 .}$ & Az emberiség jelenleg globális válsággal néz szembe. (1) & 7,41 \\
\hline $\mathbf{3 .}$ & Gyorsan és határozottan kell cselekednünk (3) & 7,34 \\
\hline $\mathbf{4 .}$ & $\begin{array}{l}\text { A következő hetekben hozott gazdasági, politikai és társadalmi } \\
\text { döntések valószínüleg az elkövetkezö években alakítják a világot. (2) }\end{array}$ & 7,14 \\
\hline $\mathbf{5 .}$ & $\begin{array}{l}\text { Egy társadalomban az embereket, az adott ország államának kell } \\
\text { megvédeni (8) }\end{array}$ & 6,64 \\
\hline $\mathbf{6 .}$ & $\begin{array}{l}\text { Ki kell várnunk, bízni kell a tudományos adatokban és az egészségügyi } \\
\text { szakemberekben. (4) }\end{array}$ & 6,04 \\
\hline $\mathbf{7 .}$ & Egy társadalomban az embereknek önmaguknak kell döntést hozni (9) & 5,32 \\
\hline $\mathbf{8 .}$ & Minden válság lehetőséget kínál (7) & 5,07 \\
\hline $\mathbf{9 .}$ & Egy nagyszabású társadalmi kísérlet részesei vagyunk (5) & 4,72 \\
\hline $\mathbf{1 0}$ & Az emberek választhatnak a magánélet és az egészség között (6) & 4,37 \\
\hline
\end{tabular}

Forrás: saját elemzés 
Amennyire meglepetésként érte Magyarországot a koronajárvány és az azzal járó intézkedések sorozata, olyannyira érdekesek a sztoikus válaszok arra a kérdésre, amely a meglepetéssel kapcsolatban kérdezett rá. A válaszadók véleményét ugyanis három dolog határozta meg: egyrészt a többség saját elmondása szerint egyáltalán „semmin” nem lepődött meg, míg a második és harmadik legfontosabb okai a döbbenetnek „,mások felelötlensége”, illetve az „emberi felelötlenség”, illetve a „politikusok felelőtlensége” jelentette. A személyesebb vonalat a munkahellyel kapcsolatos bizonytalanságok ingatták meg legerösebben, másrészt a helyzet ismeretlensége, harmadrészt a bizonytalansággal járó személyes labilitás és veszteség érzet súlya. Annak ellenére, hogy a válaszadók $81,1 \%$ állította, hogy hisz a szolidaritásban, nem mehetünk el szó nélkül amellett, hogy az én és MÁSOK szembesítése mellett egy teljes társadalmi csoport vált a kirekesztés célpontjává, hiszen az első adatok és értelmezések szerint az idősek számára jelent a vírus a nagyobb kockázatot.

\author{
„Még mindig látni idöseket az utcákon.” \\ „Az, hogy sok idös ember van az utcákon.” \\ „Az emberek nem fogják fel, mit jelent az otthonmaradás ,..
}

Ennek érdekében számos korlátozás és intézkedés született a kijárási korlátozások idején a 65.életévüket betöltők számára, holott a fiatalabbak, akik halmozottan, vagy rejtetten súlyosabb betegségekkel bírnak, nagyobb kockázatot jelentenek a betegséggel szemben. Az időskorúakkal szemben felmerült türelmetlenség és hibáztatás a kialakult hangulatban nehezen értelmezhető viselkedés, egyrészt azért, mert nem beazonosítható, hogy ezek a megnyilvánulások a megelőzés, óvás és védés érdekében született érzetek, vagy a véleményüket kifejezők a fertőzés terjedésének további veszélyét látják az idősekben.

\title{
7. Összefoglalás
}

A Science magazin száz évvel ezelőtt egy tanulmányt publikált a spanyol influenzajárványról. A tanulmány azt állította, hogy három fő tényező akadályozta meg a spanyolnátha világméretű járvány megelőzését: egyrészt az emberek nem ismerték fel az általuk okozott kockázatokat, az akkori technológiai és hírközlési lehetőségeket ismerve a tájékoztatás mértéke nem tudott olyan széles rétegekhez eljutni, mint napjainkban a tömegmédia és a közösségi média korában. Másrészt azt állították, hogy az emberi természettel ellentétes az, ha az emberek merev elszigeteltségben tartják magukat mások védelmében és ezért sokan renitensek voltak, nem követték az elzárkózás, a karantén követelményeit. Harmadrészt annak tulajdonították a 
járványkezelés sikertelenségét, hogy az emberek gyakran öntudatlanul folyamatosan veszélyeztetik magukat és másokat.

Sorokin (1942) a II. világháború közepén, a katasztrófák társadalmi életre gyakorolt hatásáról megjegyezte, hogy a balesetek ritkán fordulnak elö önmagukban. Sorokin elsősorban azért aggódott, hogy a betegségek a szegénység, háború vagy forradalom előfutárai.

A kutatás eredménye alapján a jelenlegi globális egészségügyi válság leküzdése után a legfontosabb kérdés az lesz, hogy vajon az emberiség a pandémia során elegendő rugalmassággal száll-e szembe az immár globális kihívásokkal. Vajon a koronavírus ideje alatt szerzett megküzdési képességek kellően hatékony társadalmi dinamikát indítottak-e el, amelyek sikeres szocializációja megkönnyítheti a hatékonyabb fellépést a későbbiekben más, globális fenyegetésekkel szemben is? Látható, hogy a fentiek közül sokak megküzdési startégiája az elkerülés mellett a pozitív jelentések keresésével párosult a helyzet leírására érdekében. Míg mások a megélhetésük és létfenntartásuk biztosításával és egy háztartásban élőként egymás elviselésével próbáltak a mindennapokban megbirkózni.

A gyerekek és az öregek elhanyagolása, a saját időben való kiteljesedésre törekvés fontos információkat adnak ahhoz, hogy betekintést nyerjünk a magyar társadalom- és magatartástudomány járványhoz kapcsolódó viszonyához. A felmérés rávilágított, hogy a fenyegetés érzékelése, a félelem eltérő képet mutat különböző társadalmi kontextusokban, míg az is megfigyelhető, hogy a kommunikáció, az egyéni és a kollektív érdekek összehangolása, valamint a stressz és a megküzdéssel kapcsolatos kollektív érzelmek sem egysíkúan kerültek megfogalmazásra.

A tanulmány elején feltett kérdésekre kapott eredmények alapján megállapítható, hogy 1.) egyéni szinten a reziliencia, a rugalmas alkalmazkodás, társadalmi szintű adaptálási képességéhez kapcsolható. 2.) Magyarországon az emberek viszonylag gyorsan és hatékonyan voltak képesek alkalmazkodni a kialakult helyzethez. 3. A reziliencia többnyire az erős családi kapcsolatok, illetve a szolidaritás érzete mentén, valamint a spiritualitás mentén tud kibontakozni.

A felhasznált hazai és nemzetközi szakirodalom alapján megfogalmazható, hogy a 21. században az egészségről szóló kommunikációból a jóléttel és közjóval kapcsolatos szempontok már egyáltalán nem hiányozhatnak, hiszen látható, hogy a félelem és a frusztráció leküzdése sokat segít a betegség megelőzésében és az életminőség érzetének javításában 
bezártság idején. Az is fontos észrevétele a kutatásnak, hogy a járvány okozta társadalmi viselkedés egy lassan kibontakozó globális szolidaritás képét vetíti elő, amely közelebb hozza azokat az embereket, akik reziliensen változni tudnak és képesek azonosulni a változással. A fenntarthatóság szempontjából csakis ezek a gondolkodásminták szavatolják, hogy az egyes társadalmak a hosszú távú fenntarthatóság szempontjából előnyösen reagáljanak a későbbiekben egy hasonló volumenű, globális korlátozásokkal járó vészhelyzet esetén. 


\section{Felhasznált irodalom}

1. Beck, Aaron T., et al. "Dysfunctional beliefs discriminate personality disorders." Behaviour research and therapy 39.10 (2001): 1213-1225.

2. Berkes, F., Folke, C. (1998): Linking social and ecological systems for resilience and sustainability. Cambridge University Press, Cambridge

3. Bonanno, George A., Camille B. Wortman, and Randolph M. Nesse. "Prospective patterns of resilience and maladjustment during widowhood." Psychology and aging 19.2 (2004): 260.

4. Bourbeau, Philippe (2013): Resiliencism: Premises and Promises in Securitisation Research. Resilience: International Policies, Practices and Discourses 1(1): 3-17. Interneten: http://philippebourbeau.net/uploads/3/5/3/2/3532952/bourbeau_resiliencism_final_versio n_resilience_2013.pdf. (letöltés dátuma: 2020.07.27)

5. Boris Johnson radikális fordulata: Anglia is bezár, rendőri segítséggel https://mfor.hu/cikkek/makro/boris-johnson-radikalis-fordulata-anglia-is-bezar-rendorisegitseggel.html

6. Campanella, T. (2006): Urban resilience and the recovery of New Orleans. Journal of the American Planning Association, 2., 141-146. http://doi.org/cgcp4p

7. Coaffee, J. (2008): Risk, resilience, and environmentally sustainable cities. Energy Policy, 12., 4633-4638. http://doi.org/b9h5vf

8. Cole, S., Balcetis, E. és Dunning, D. Affective signals of threat increase perceived proximity. Psychol. Sci. 24, 34-40 (2013).

9. Corkery, M., és Maheshwari, S. (2020, mar). Is There Really a Toilet Paper Shortage? Retrieved from https://www.nytimes.com/2020/03/13/business/ toilet-papershortage.html

10. Coronavirus: WHO advises to wear masks in public areas https://www.bbc.com/news/health-52945210 (letöltés dátuma: 2020. 07.27)

11. DÁVID Imre-FÜLÖP Márta-PATAKY Nóra-RUDAS János (Szerk.) (2014): Stressz, Megküzdés, Versengés, Konfliktusok. MAGYAR TEHETSÉGSEGÍTÖ SZERVEZETEK SZÖVETSÉGE. https://tehetseg.hu/sites/default/files/konyvek/geniusz_34_net.pdf

12. Digitális gazdaság és társadalom, $2018 \mathrm{KSH}$ https://www.ksh.hu/docs/hun/xftp/idoszaki/ikt/ikt18.pdf

13. Elcheroth, G. , és Reicher, S. (2017). Identity, violence, and power. Mobilising hatred, demobilising dissent. London, UK: Palgrave Macmillan.

14. Eurocities. 2020. "Live Updates COVID-19European Cities Respond to the Coronavirus CrisisZaragoza - Support for Young, Old and Victims of Gender ViolenceEUROCITIES.” Live Updates COVID-19. April 6, 2020. https://covidnews.eurocities.eu/2020/04/06/zaragoza-support-for-young-old-and-victimsof-gender-violence/ (letöltés dátuma: 2020. 07.27)

15. Folke, C. (2006): Resilience: The emergence of a perspective for social-ecological systems analyses. Global Environmental Change, 3., 253-267. http://doi.org/bm28fh 
16. Folkman, S.-Lazarus, R. S. (1988): Coping as a mediator of emotion. Journal of Personality and Social Psycholgy, 54, 466-475

17. Fricker, R. D., és Schonlau, M. (2002). Advantages and disadvantages of Internet research surveys: Evidence from the literature. Field methods, 14(4), 347-367.

18. Füstös L.: Látens változós modellek. Értékindikátorok. Magyarország, Európa és Kína értékrendszere, értéktere. Módszertani füzetek 2018/1. Budapesti CORVINUS Egyetem, Gazdálkodástudományi Kar Informatikai Intézet, TEAM, Társadalmi elemzések Alkalmazott Mühelye. 270 oldal.

19. Grotberg, E. H. (1996). The International Resilience Project: Findings from the Research and Effectiveness of Interventions. (kézirat). Forrás:

http://resilnet.uiuc.edu/library/grotb97a.html (letöltés dátuma: 2020. 07.27)

20. D. Kahneman, P. Wakker, R. Sarin Back to Bentham? Explorations of experienced utility Quarterly Journal of Economics, 112 (1997), pp. 375-405 Thorne-Henley; 2

21. Kelland K.: Wear masks in public says WHO, in update of COVID-19 advice https://www.reuters.com/article/us-health-coronavirus-who-masks/wear-masks-in-publicsays-who-in-update-of-covid-19-advice-idUSKBN23C27Y (letöltés dátuma: 2020. 07.27)

22. Keogh, D. U., Apan, A., Mushtaq, S., King, D., Thomas, M. (2011): Resilience, vulnerability and adaptive capacity of an inland rural town prone to flooding: A climate change adaptation case study of Charleville, Queensland, Australia. Natural Hazards, 2., 699-723. http://doi.org/dx2mjm

23. Krekó Péter - Győri Lóránt- Molnár Csaba- Takácsy Dorka : Milyen jövő vár Európára a koronavírus után? Friedrich Ebert Alapítvány http://library.fes.de/pdf-

files/bueros/budapest/16375.pdf (letöltés dátuma: 2020. 07.27)

24. Lang, T. (2011): Urban resilience and new institutional theory - A happy couple for urban and regional studies? In: Müller, B. (ed.): German Annual of Spatial Research and Policy. Springer, Berlin, Heidelberg, 9-18. http://doi.org/cpxrmw

25. Leder, J., és Betsch, T. (2016). Risky choice in interpersonal context: Do people dare because they care? Journal of Economic Psychology, 52, 1-23.

https://doi.org/10.1016/j.joep.2015.11.003

26. Malhotra, N. K., Kim, S. S., és Agarwal, J. (2004). Internet users' information privacy concerns (IUIPC): The construct, the scale, and a causal model. Information systems research, 15(4), 336-355.

27. Messick, D. M., és McClintock, C. G. (1968). Motivational bases of choice in experimental games. Journal of Experimental Social Psychology, 4(1), 1-25.

28. Miklós, Ilona (2018) A magyar földrajzi árujelzős élelmiszerek észlelési térképe: a magyar vásárlók értékdimenziói = Detection map of Hungarian food products with geographical indications: value dimensions of Hungarian consumers. $\mathrm{PhD}$ thesis, Budapesti Corvinus Egyetem, Gazdálkodástani Doktori Iskola.

29. Mobbs, D., Hagan, C. C., Dalgleish, T., Silston, B. és Prévost, C. The ecology of human fear: survival optimization and the nervous system. Front. Neurosci. 9, 55 (2015). 
30. Most akkor megbukott a svéd koronavírus-modell, vagy nekik volt igazuk? https://hvg.hu/vilag/20200719_svedorszag_koronavirus_fertozes (letöltés dátuma: 2020. 07.27)

31. Neulinger, Á. (2016). Több-módszertanú és vegyes módszertanú kutatások. Vezetéstudomány/Budapest Management Review, 47(4), 63-66.

32. Peters, G. J. Y., Ruiter, R. A. C., és Kok, G. (2013). Threatening communication: A critical reanalysis and a revised meta-analytic test of fear appeal theory. Health Psychology Review, 7(SUPPL1), 8-31. https://doi.org/10.1080/17437199.2012.703527

33. Pszichiátria a járvány idején: szakmai segítő anyagok gyüjteménye, MPT http://www.mptpszichiatria.hu/hirek.aspx?nid=99235és cid=468 (letöltés dátuma: 2020. 07.27)

34. Pszichiátria a járvány idején: szakmai segítő anyagok gyüjteménye, MPT http://www.mptpszichiatria.hu/hirek.aspx?nid=99235és cid=468 (letöltés dátuma: 2020. 07.27)

35. Rimal, Rajiv N., and Hee-Soon Juon. "Use of the risk perception attitude framework for promoting breast cancer prevention." Journal of Applied Social Psychology 40.2 (2010): 287-310.

36. Robinson, Guy M., and Doris A. Carson. "Resilient communities: transitions, pathways and resourcefulness." The Geographical Journal 182.2 (2016): 114-122.

37. Spéder, Zs. 2006. Kultúrák, értékek, normák, szocializáció. In: Andorka Rudolf: Bevezetés a szociológiába. Budapest: Osiris Kiadó. pp. 357-367. Osiris Kiadó Budapest 2006

38. Szabó-Tóth Kinga - Szepessy Péter: Szellem és Tudomány 2020/2 file:///D:/v\%C3\%ADrus/SzellemesTudomany2020_2.pdf (letöltés dátuma: 2020. 07.27)

39. Székely Iván: Reziliencia: a rendszerelmélettől a társadalomtudományokig, Replika 94, 7-23. http://www.replika.hu/replika/94-01 (letöltés dátuma: 2020. 07.27)

40. Sheeran, P., Harris, P. R., és Epton, T. (2014). Does heightening risk appraisals change people's intentions and behavior? A meta-analysis of experimental studies. Psychological Bulletin, 140(2), 511-543. https://doi.org/10.1037/a0033065

41. Sorokin, P. A. (1942/2017). Man and society in calamity. London, UK; New York, NY: Routledge

42. Soper, G. A. The lessons of the pandemic. Science 49, 501-506 (1919).

43. Vallacher, Robin R., Stephen J. Read, and Andrzej Nowak. "The dynamical perspective in personality and social psychology." Personality and Social Psychology Review 6.4 (2002): 264-273. 